\title{
ERRORS WITH AND WITHOUT PURPOSE: A. MARDKOWICZ'S TRANSCRIPTION OF ŁUCK-KARAIM LETTERS IN HEBREW SCRIPT
}

\begin{abstract}
In the sixth volume of the Karaim journal Karaj Awazy Aleksander Mardkowicz (1875-1944) prepared a six page long article containing reminiscences of the loft in kenesa in Łuck (Mardkowicz 1933b) and a transcription of seven letters found there (Mardkowicz 1933a). Detailed comparison of five of those manuscripts with their transcriptions (we do not know what happened to the remaining two manuscripts) shows that Mardkowicz's readings are not free from certain shortcomings and errors. Besides a few obvious printing errors, one can find not only erroneous readings, but also a considerable number of changes that had been made intentionally, fragments that had been passed over, translations of Hebrew fragments that had not been noted, and words that exhibited evident Troki or Crimean Karaim phonetic features but which had been transcribed in such a way as though they had been written in Łuck Karaim. The reason for these intentional amendments to the text of the original manuscripts can probably be ascribed to the fact that Mardkowicz - who played a vital role in the Karaim language purism movement - tended to use "normative Karaim" in his journal, even at the price of modifying the content of the letters. The examples of these misrepresentations have been grouped into the following categories: 1) intentional amendments concerning phonetic, morphologic and phonotactic features and dialectal affiliation of the word forms; 2) erroneous readings of Karaim words and Hebrew abbreviations and, finally, 3) translating Hebrew fragments without noting it. The article does not deliver a full critical edition of the manuscripts, as this is going to be the subject of another, much more comprehensive, study, where the facsimiles of the letters will also be published.
\end{abstract}

\section{Introduction}

In the sixth volume of the Karaim journal Karaj Awazy, published as a result of the efforts and financial support of Aleksander Mardkowicz (1875-1944), the publisher prepared a six page long article containing reminiscences of the loft in kenesa in Łuck 
(Mardkowicz 1933b) and a transcription of seven letters found there (Mardkowicz 1933a). These letters are almost all that is left of a great collection which had been stored in the loft and gradually destroyed during the First World War and the Russian Revolution in 1917 (the history of the kenesa has been described by Sulimowicz A. 2008). ${ }^{1}$ The manuscripts that remained intact during the periods of war ended up in Józef Sulimowicz's (1913-1973) collection ${ }^{2}$ and are in very good condition, what allowed us to undertake a comparison of five of those manuscripts ${ }^{3}$ with their transcriptions. ${ }^{4}$ This is especially important in the case of Karaim, because there are very few sources written in the colloquial language; the value of the proper editions cannot therefore be underestimated. Indeed, Pritsak's statement, although published exactly fifty years ago, is still true: "Der wesentliche Teil der Handschriften harrt noch immer der Veröffentlichung und Bearbeitung" (Pritsak 1959: 324).

The goal of the present article is to show what kinds of amendments can be made to Mardkowicz's readings. We do not plan to deliver a full critical edition of the manuscripts here, as this is going to be the subject of another, much more comprehensive, study (which is already in preparation), where the facsimiles of the letters will also be published.

\section{Mardkowicz's transcription}

It has to be stated at the outset that Mardkowicz did not intend to prepare a professional critical edition of the letters. His aim was only to show to the latest generation "what their ancestors wrote about and how they did it." ${ }^{, 5}$ Therefore, his study lacks any com-

\footnotetext{
${ }^{1}$ Mardkowicz (1933b: 4-5) recalls his childhood, the period when the floor of the loft used to be covered with sheets of paper and describes what had been left after the war. This is what the author writes: "Enk kićli magnit, kajsy tartaredi meni joharyha, edi kahytłar. [...] Bitin babinec tesegen edi ałarba [...]. [...] tabaredim anda ajryc siflerin ułłu seferłerin, zemerłer kerkli jazysba jazhan, bitikłer kełgen bundahy dzymatka ezge dzymatłardan, kahytłar urusca da esawca jazhan da mohorłahan kyzył da kara mohorłarba. [...] Da muna jyłdyrym kibik jaryk kegiziden urdu tawułu ceriwnin. Tigendi ceriw, keldi anyn korkuncłu sonhusu — rewolucija. [...] Tezeredi meni muzhuł chabar: keldi uc babinecke! [...] Kergizdłer mana miwisinde kenasanyn ułłu-tiwił kap kahytłarba. Bu edi bary ne kałdy oł sansyz chaznasyndan jazysłarnyn [...].” [= transl.: The most powerful magnet which attracted me upstairs was the papers. [...] The whole loft was covered with them [...]. [...] I used to find there separate sheets from thick books, religious poems written in beautiful writing, letters that had been sent to this community from other Karaim communities, papers written in Russian and Polish sealed up with red and black seals. [...] And, behold, like a bolt from the blue, the storm of war broke out. The war ended, its terrible ending - the revolution came. [...] Sad news waited for me: the loft did not exist anymore! [...] They showed me a small sack with papers in the corner. That was all that was left of the countless treasures of writing [...].].

${ }^{2}$ This is considered to be one of the largest collections of Karaim manuscripts in Poland (cf. Dubiński 1979: 148).

${ }^{3}$ We are indebted to Anna Sulimowicz for drawing our attention to these sources.

${ }^{4}$ Letters numbered I, II, III, V and VI in Mardkowicz's (1933a) article. The letters appear in J. Sulimowicz's (1972) archive under the following catalogue numbers: 2(77), 51, 43, 9 and 3(78), respectively. Unfortunately, we do not know where the remaining two manuscripts are or what happened to them.

${ }^{5}$ This is what we can read in Mardkowicz (1933b: 5): "Hali tutamen kołumda neceni of kart da sarharhan sifcekłerden, kajsyłar kacanes teseredłer tipin babinecnin. Da keldi basyma sahys bastyrma ałarny, ki kergizme haligi dorha ne da necik jazaredłer atałarymyz." [= transl.: Now I hold in my hand some of those old and yellowed sheets, which once used to be spread over the loft's floor. And the idea of printing them
} 
ments on the text itself, such as on its spelling errors, clerical errors, amendments introduced by the authors, orthography and so on. For reprinting the letters, Mardkowicz used the Łuck Karaim orthography (which was commonly used at that time) based on Polish writing in order to make them comprehensible to the reader. In fact, we probably should not expect more in a journal that did not aspire to be strictly "academic," especially given that the author's "transcribing system" is quite transparent. ${ }^{6}$

A closer examination of the manuscripts, however, shows that Mardkowicz's readings are not free from certain shortcomings and errors. As will be argued below, besides a few obvious printing errors, ${ }^{7}$ which are in fact clear to the reader, we were able to find not only erroneous readings, but also a considerable number of changes that had been made intentionally, fragments that had been passed over, ${ }^{8}$ translations of Hebrew fragments that had not been noted (see e.g. the heading of letter III originally written in Hebrew), and words that bore evident Troki or Crimean Karaim phonetic features but which had been transcribed in such a way as though they had been written in Łuck Karaim. The latter is characteristic first of all of letter III, in which the number of such words, originally attested with evident Troki Karaim phonetic and morphologic features, amounts to approximately twenty-five. It should be noted that this is a relatively large number, given that the manuscript consists of merely forty lines. As the considerable part of the manuscript can be interpreted both as written in Troki or Łuck dialect, we would even venture to suggest that the letter has been originally written in Troki dialect with Łuck Karaim elements.

The reason for these intentional amendments to the text of the original manuscripts can probably be ascribed to the fact that the author tended to use "normative Karaim" in his journal, even at the price of modifying the content of the letters. He even mentioned in the introduction to the letters that the language their ancestors used to speak was not pure, as they mixed it with Russian and Polish words. ${ }^{9}$ When seen in this light, his intention was definitely not to misrepresent certain details of the manuscripts, but to promote - to the highest possible degree - the fluency of Karaim among what was then the younger generation. ${ }^{10}$ Consequently, these above mentioned shortcomings should be judged in the context of the language purism movement, which became stronger during

came to mind, in order to show to the present generation what our ancestors wrote about and how they did it.].

${ }^{6}$ We use the same transcription in the present article - for the sake of consistency. The following symbols might need to be explained here: $\mathrm{ch}=[\chi], \mathrm{h}=[\mathrm{h}], \mathrm{sz}=[\check{\mathrm{s}}], \mathrm{w}=[\mathrm{v}]-$ i.e. as it was rendered in the prewar Polish orthography.

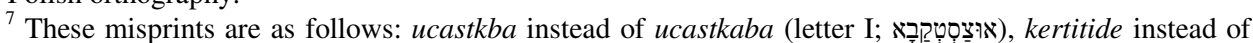

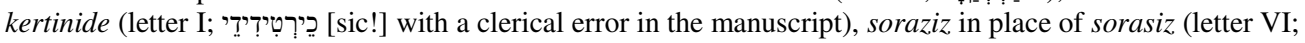
(סiס (סרסיז) and a redundant full stop after ispotnitme in the penultimate paragraph of letter VI.

${ }^{8}$ Only two fragments: 1) the word uttu is noted only once in letter VI, however we can clearly see uttu uttu (אוּללו: אוללוi) in the manuscript; 2) the fragment da mucettiniz ik $a$ is passed over in the same paragraph of letter VI

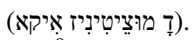

${ }_{9}$ Mardkowicz (1933b: 5): "Sezi oł bitikłernin tiwildi aruw karaj sezi. Tabasiz ałarda kep jat sezłer, dahanłahan rus da lech tiłden" [= transl.: The language of those letters was not pure Karaim. We can find in them many foreign words, borrowed from Russian and Polish.].

${ }^{10}$ The importance of this was for him is shown, for example, in the first tale ever written in Karaim entitled Elijahunun исиги. In the foreword Mardkowicz (1930: 3) "assures" the reader that their language is not "poor and imperfect" and has to be cultivated. The translation of the foreword has been delivered by Csató (2002: 137-138). 
the interwar period and based itself upon a similar kind of movement that had emerged in Turkey (Dubiński 1982: 143). It should be emphasized that Mardkowicz played a vital role in the movement, and his efforts to preserve the language by adjusting it to every-day life were particularly significant (for further reading see, for example, A. Sulimowicz 1987: 28-29). His efforts to preserve Karaim by avoiding the use of Slavonic, mostly Polish, Ukrainian and Russian, words, have been noticed and appreciated, even in Troki where a similar movement had been established at that time (see e.g. Firkowicz 1935-1936). ${ }^{11}$

When seen in this light, it is hard to escape the conclusion that the texts of the remaining two letters published by Mardkowicz (1933a) and, perhaps his other works that presented manuscripts, should be treated somewhat cautiously.

The examples presented below - two for each type of misrepresentation - will suffice to illustrate this argument. We grouped them into the following categories: 1) intentional amendments concerning phonetic, morphologic and phonotactic features and dialectal affiliation of the word forms; 2) erroneous readings of Karaim words and Hebrew abbreviations and, finally, 3) translating Hebrew fragments without noting it. All the examples mentioned here are clearly legible in the relevant manuscripts.

\section{Examples}

\subsection{Intentional amendments}

a) Phonetics

הוֹדְדָ (letter I, $5^{\text {th }}$ paragraph)

THERE IS: goddan 'year (DAT)'

SHOULD BE: hoddan id.

CONTEXT: nowyj hoddan hanuz kirmedi kaznaha jasakta bir choros "since the New Year even a grosz did not come to the treasury for the tax'

COMMENTARY: To the best of our knowledge, the letter he 〈ה〉 was never used for denoting [g] in Łuck Karaim manuscripts or even in Karaim written sources in general (cf. e.g. Zajączkowski 1931-1932: 184 et passim, J. Sulimowicz 1972: 43 or Jankowski 1997: 4-5 for notes on the orthography of Troki and Crimean Karaim manuscripts, respectively). ${ }^{12}$ In Łuck Karaim texts, in the vast majority of cases, he renders the velar

\footnotetext{
${ }^{11}$ This is, in point of fact, what Altbauer (1979-1980) has written about. However, he placed this phenomenon in a slightly different light. In his opinion, replacing the Hebrew lexicon with native words in, for example, the Karaim translation of the Book of Lamentations performed by J. Łobanos (chazzan in Vilnius in years 1929-1937 and in Łuck for two years: 1938-1939) was not the result of language purism but should rather be explained by the translator's desire to reflect the slight stylistic differences of the original Hebrew text (Altbauer 1979-1980: 53). Yet, the fact that J. Łobanos had been in charge of a youth group for several years (a youth group whose goal was to learn and preserve their mother tongue) and the fact that he also in his publications tended to follow the achievements of the Turkish language reforms casts doubt on such an assumption (cf. Dubiński 1982: 144; 1995: 62).

${ }^{12}$ What we can read in Tekin / Ölmez (2003: 129), namely that the letter 〈ה〉 was used to mark [g] in loanwords, seems to be doubtful. Works enumerated in the references (Tekin / Ölmez 2003: 130) lack such
} 
voiced spirant [h]. It was, furthermore, used very rarely to indicate a final $-a$ or $-e$, mostly in Hebrew borrowings. If the word in question was pronounced with $g$-, we would expect a gimel $\langle\lambda$ in place of $h e$.

The etymon of the word is Russ. год 'year' but, at the same time, the author of the letter pronounced it probably with the initial $h$ - due to the Ukrainian habits of articulation (Ukr. [h] corresponds to Russ. [g]). Finally, the probable reason as to why Mardkowicz altered the transcription is the fact that Ukrainian-like pronunciation sounded more colloquial than the Russian-like one. Compare this with the next remark.

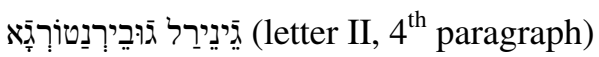

THERE IS: generat gubernatorha 'governor general (DAT)'

SHOULD BE: henerat hubernatorha id.

CONTEXT: jazdymda ese uze henerat hubernatorha 'if I wrote directly to the governor general'

COMMENTARY: The letter gimel with a macron $\langle\bar{\lambda}\rangle$ was regularly used for representing the velar voiced spirant $[\mathrm{h}]$ in the discussed manuscripts - as it was in other dialects, too (cf. Zajączkowski 1931-1932: 187 et passim, J. Sulimowicz 1972 loc. cit., Jankowski 1997 loc. cit.). If the author of the manuscript had pronounced the initial $g$ here, he definitely would have used a simple gimel in writing. What makes the transcrip-

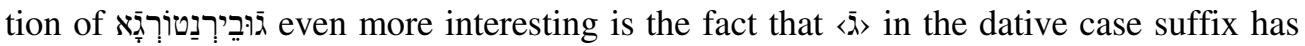
already been transcribed with $-h$ - by Mardkowicz. For an explanation of the $g->h$ change and a brief explanation of Mardkowicz's altered reading, cf. the commentary in the previous remark.

b) Morphology

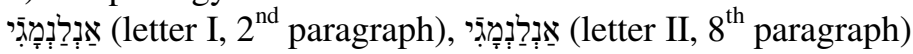

THERE IS: antamahy 'understanding (POSS.3.SG)'

SHOULD BE: antanmahy 'meaning, sense (POSS.3.SG)'

CONTEXT: I) ochunuz bu bitikni da esiniźni kojunuz jachsy necikti antanmahy 'read this letter and pay close attention to what its meaning is'; II) to antanmahy $k i$ 'thus the meaning of this is that'

COMMENTARY: The word antanmak is a -mak derivative of the $-n$ reflexive form (cf. Zajączkowski 1932: 113) of the verb anta- 'to understand.'

Theoretically, the lack of an inner $-n$ - in the transcription could have been a result of a printing (and therefore unintentional) error, but the same amendment occurs twice in the letters. This suggests that Mardkowicz used the form antamahy because this is how he would have written the word in these particular contexts. Even if the correctness of the word he suggests is beyond doubt, we believe that since the word appears on two separate occasions in different manuscripts and possesses an identical meaning, the notion that this might be a clerical error in the manuscript can be ruled out. The reflexive form could be, in fact, explained as a calque of Pol. rozumie się 'it means' (cf. e.g. przez to rozumie się... 'this means...') or Russ. разумеется 'it means.'

information. In fact, this might be a misprint (possibly $g$ written instead of $\dot{g}$ ), as in the table provided by the authors, the phoneme $[\mathrm{h}]$ is not mentioned at all. 


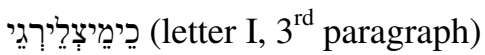

THERE IS: kemecterni 'soldier (ACC.PL)'

SHOULD BE: kemecterge 'soldier (DAT.PL)'

CONTEXT: ałaj bujurhandy ki bez oceredi atma kemecterge 'it had been ordered to take [people] out of turn [= immediately] to the army'

COMMENTARY: The dative case written with a gimel (with tzere) and a yod is clearly legible. The reason why Mardkowicz made this correction could have been the fact that the expression kemecterge atma calques Russ. взять в солдаты 'to induct into the army' and might have sounded too colloquial.

c) Phonotactics

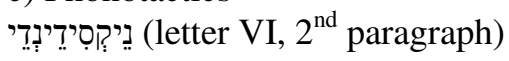

THERE IS: nekisidende 'nobody (ABL, partic. -de)'

SHOULD BE: neksidende id.

CONTEXT: kabut etmedik neksidende 'we did not receive from anyone'

COMMENTARY: Morphologically, this word form consists of nekisi 'nobody,' the ablative case suffix -den and the generalising particle -de. In this case there is no doubt that the syllabic structure of the word has been reduced as a result of a fairly common phenomenon in Karaim (and in the Turkic languages in general) - the syncopation of a high vowel in a syllable followed by a syllable with another high vowel. Mardkowicz shows the grammatically correct as opposed to the colloquial form of the word. The notion of a printing error in Mardkowicz's work and / or a slip of the pen in the manuנֵיקְִיגיגיריא neksigede 'nobody (DAT, partic. -de)' transcribed as nekisigede in the same paragraph of this letter.

A trace of the same kind of amendment can be seen, for example, in בְִּ baknyz 'take care of (IMPERAT.2.PL)' published in letter II as bakynyz ( $8^{\text {th }}$ paragraph).

d) Dialectal variants

$$
\text { קהלייזדן (letter III, } 2^{\text {nd }} \text { paragraph) }
$$

THERE IS: kahatynyzdan 'Karaim community (POSS.2.PL, ABL)' (KarŁ.)

SHOULD BE: kahałyjyzdan id. (KarT.)

CONTEXT: ekińci bitik keldi mana kahałyjyzdan 5. podpisba 'the second letter came to me from your community with five signatures'

COMMENTARY: One of the main characteristic features of Troki Karaim is the development of [y] into [j] by contrast with [n] in the Łuck dialect. We can clearly see this $-j$ in the 2.PL possessive suffix of the quoted example (for $\eta>j$ development cf. e.g. Kowalski 1929: xxxi). Such examples clearly show that Mardkowicz replaced the northern form with a southern one in order to ensure that the text sounded "purer." (Cf. the next note.)

בוּרִיי (letter III, $6^{\text {th }}$ paragraph)

THERE IS: butaj 'this way, in this manner' (KarŁ.)

SHOULD BE: butej id. (KarT.)

CONTEXT: kyłarsyz butej 'you will act in this manner' 
COMMENTARY: The $a>e$ palatalisation process in the final segment $-a j>-e j$ is one of several features that is characteristic of Troki Karaim (cf. e.g. Kowalski 1929: xxxixxxii). The form butej has simply been replaced by the Łuck Karaim one. (Cf. the previous example.)

\subsection{Erroneous readings}

a) Changing the content of the sentence

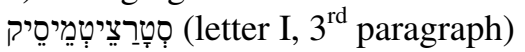

THERE IS: staracetmesen 'to make an effort (COND.NEG.2.SG)'

SHOULD BE: staracetmesek 'to make an effort (COND.NEG.1.PL)'

CONTEXT: a eger staracetmesek 'but if we do not make any effort'

COMMENTARY: The final qof 〈p〉, although being similar in the Karaim semi-cursive script to final nun 〈\}, is clearly legible in the manuscript.

בִילִינִיז (letter VI, $4^{\text {th }}$ paragraph)

THERE IS: bitesiz 'to know (PRAES.2.PL)'

SHOULD BE: biliniz 'to know (IMPERAT.2.PL)'

CONTEXT: biliniz siwer da abajty dosttarym 'may you know, my dear and honoured friend'

COMMENTARY: The word בִילִיניניז biliniz is clearly legible in the manuscript. The plural form of the verb is used to express respect here, what is a common phenomenon in Karaim.

b) Erroneous reading of Hebrew abbreviations כמוהרר ביים ר' שלמהדין (letter II, $2^{\text {nd }}$ paragraph)

THERE IS: k.m. Szetomo Beimden 'the Honourable Szełomo Beim'

SHOULD BE: k.m.w.h.r.r. Beim r. Szotemeden 'the Honourable and the rabbi, sir Szołeme Beim'

CONTEXT: kabut ettim bitik Krymdan כמוהרר Beim רetemeden 'I received a letter that was sent from the Crimea from the Honourable and the rabbi, sir Szołeme Beim'

COMMENTARY: The abbreviation כמוהרר stands for Hebr. כבוד מעלת והרב רבי כhe Honourable and the rabbi' or Hebr. כבוד מורינו הרב רב : כour honourable teacher, the rabbi'

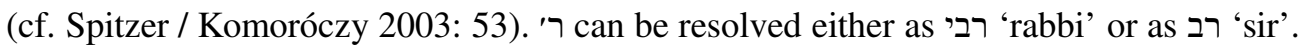
Mardkowicz transcribed here only כמר מעלת 'the Honourable' (Hebr. כמד מעי - this honorific was used widely amongst Karaims (cf. KarT. k'evot maałat cited by Kowalski 1927: 223). Whether Mardkowicz passed over the last element of the abbreviated honorific (כמוהרר) simply because the title rabbi was no longer used in the interwar period (if this was the case we should treat this as an intentional change), must for the time being remain speculative.

The name Szoteme was a variant of Hebr. שלמה used by Crimean Karaims (cf. e.g. Szapszał 1932-34: 10), what fits in well with the fact that the person in question originated from the Crimea (see KBS 21, s.v. Беим Соломон Абрамович). This reading explains why the front variant of the ablative case suffix had been attached to the name. 


\subsection{Translating Hebrew fragments without notification}

החתן (letter V, $5^{\text {th }}$ paragraph)

THERE IS: chatan 'bridegroom'

SHOULD BE: hachatan 'the bridegroom'

CONTEXT: [as a signature:] ' החתן 'Mosze 'bachelor Moshe the bridegroom'

COMMENTARY: The word chatan (< Hebr. חתן 'bridegroom'), which already entered Łuck and Troki Karaim (or at least we can find it in the dictionaries, see: Mardkowicz 1935: 27; KRPS 602; Çulha 2006: 66), had been used in the manuscript with the Hebr. definite article $\mathrm{n}$. (Cf. the next word.)

הכלה (letter V, $5^{\text {th }}$ paragraph)

THERE IS: ot katta 'the bride'

SHOULD BE: hakatta id.

CONTEXT: [as a signature:] Chana הכלה 'Chana the bride'

COMMENTARY: The Hebr. definite article $\pi$ was replaced in Mardkowicz's work by the demonstrative pronoun $o t$, which was occasionally used in this role (cf. e.g. Pritsak 1959: 331). The word katta 'bride' (< Hebr. כלה id.) was in widespread use in Karaim (cf. Mardkowicz 1935: 39; KRPS 287).

\section{Abbreviations}

$$
\begin{aligned}
& \mathrm{ABL}=\text { ablative } \\
& \mathrm{ACC}=\text { accusative } \\
& \text { COND = conditional } \\
& \mathrm{DAT}=\text { dative } \\
& \text { IMPERAT }=\text { imperative } \\
& \text { NEG }=\text { negation } \\
& \text { PARTIC = particle } \\
& \text { PL = plural } \\
& \text { POSS = possessive } \\
& \text { SG }=\text { singular }
\end{aligned}
$$

$$
\begin{aligned}
& \text { Hebr. }=\text { Hebrew } \\
& \text { KarŁ. = Łuck Karaim } \\
& \text { KarT. = Troki Karaim } \\
& \text { Pol. = Polish } \\
& \text { Russ. = Russian } \\
& \text { Ukr. = Ukrainian }
\end{aligned}
$$

\section{References}

Altbauer M. 1979-1980. O tendencjach dehebraizacji leksyki karaimskiej i ich wynikach w „Słowniku karaimsko-rosyjsko-polskim”. - Ševčenko I., Sysyn F.E. (eds.) Eucharosterion: Essays presented to Omeljan Pritsak on his sixtieth birthday by his colleagues and students. [Harvard Ukrainian Studies 3/4, part 1]. Cambridge, MA.

Csató É.Á. 2002. The Karaim language in Halych. - Novohat'ko L., Fedoruk O., Beregovśkij O. (eds.) The Halych Karaims: History and culture. [Materials of International Conference, Halych, 6-9 September 2002]. Halyč: 135-139. 
Çulha T. 2006. Karaycanın Kısa Sözvarlığı. Karayca-Türkçe Kısa Sözlük. [Dil ve Edebiyat Dizisi 6]. İstanbul.

Dubiński A. 1979. Karaimische Handschriften in polnischen Sammlungen. - Central Asiatic Journal 23/3-4: 147-150.

Dubiński A. 1982. Polonya Karayların Türkiye Türkçesiyle ilişkileri. [IV. Milletler Arası Türkoloji Kongresi, İstanbul 20-25.IX.1982]. İstanbul. - [reprinted in:] Dubiński A. 1994. Caraimica. Prace karaimoznawcze. Warszawa: 141-144.

Dubiński A. 1995. Obnovlenie karaimskogo jazyka v pervoj polovine našego stoletija. - Rocznik Orientalistyczny 49.2: 59-63.

Firkowicz Sz. 1935-1936. Przyczynek do zagadnienia wpływów obcych na język karaimski. - Myśl Karaimska 11: 69-72.

Jankowski H. 1997. A Bible translation into the Northern Crimean dialect of Karaim. - Studia Orientalia 82: 1-84.

KBS = Eljaševič B.S. 1993. Karaimskij biografičeskij slovaŕ (ot konca XIII v. do 1960 g.) (= Institut Ėtiologii i Antropologii RAN. Materialy k serii "Narody i kultury”. Vypusk 14., Karaimy. Kniga 2). Moskva.

Kowalski T. 1927. Pieśni obrzędowe w narzeczu Karaimów z Trok. - Rocznik Orjentalistyczny 3: 216254.

Kowalski T. 1929. Karaimische Texte im Dialekt von Troki. Eingeleitet, erläutert und mit einem karaimisch-polnisch-deutschen Glossar versehen. [Prace Komisji Orjentalistycznej Polskiej Akademji Umiejętności 11]. Kraków.

KRPS = Baskakov N.A., Šapšal S.M., Zajončkovskij A. (eds.) 1974. Karaimsko-russko-pol'skij slovaŕ. Moskva.

Mardkowicz A. 1930. Elijahunun ucuru. [Bibljoteczka karaimska 1]. Łuck.

Mardkowicz A. 1933a. Jedi bitik. - Karaj Awazy 6: 6-10.

Mardkowicz A. 1933b. Sahyncyna „babinecnin“. - Karaj Awazy 6: 1-6.

Mardkowicz A. 1935. Karaj sez-bitigi. Stownik Karaimski. Karaimisches Wörterbuch. Łuck.

Pritsak O. 1959. Das Karaimische. - Deny J. et al. (eds.) Philologiae Turcicae Fundamenta. Wiesbaden: $318-340$.

Spitzer Sh.J., Komoróczy G. 2003. Héber kútforrások Magyarország és a magyarországi zsidóság történetéhez a kezdetektöl 1686-ig. Budapest.

Sulimowicz A. 1987. Karaimi w Polsce i na Litwie (do 1945 roku). - Dubiński A., Śliwka E. (eds.) Karaimi (materiały z sesji naukowej). [III Pieniężnieńskie spotkania z religiami. Materiały i Studia Księży Werbistów 32]. Pieniężno: 20-29.

Sulimowicz A. 2008. Kenesa karaimska w Łucku w świetle dokumentów z archiwum gminy. - Bairašauskaitė T., Kobeckaitė H., Miškinienė G. (eds.) Orientas Lietuvos Didžiosios Kunigaikštijos visuomenès tradicijoje: totoriai ir karaimai (= Straipsnių rinkinys, parengtas pranešimu, skaitytu tarptautineje mokslo konferencijoje „610-osios totoriu ir karaimu isikūrimo Lietuvos Didžiojoje Kunigaikštijoje metinès “ $2007 \mathrm{~m}$. rugsejo 13-15 d. Vilniaus universitete, pagrindu). Vilniaus: 273-281.

Sulimowicz J. 1972. Materiał leksykalny krymskokaraimskiego zabytku językowego (druk z 1734 r.). - Rocznik Orientalistyczny 35.1: 37-76.

Szapszał S.M. 1932-1934. Adam Mickiewicz w gościnie u Karaimów. - Myśl Karaimska 10.10: 1-10.

Tekin T., Ölmez M. 2003. Türk dilleri. Giriş. İstanbul. 
Studia Linguistica vol. 126/2009

Zajączkowski A. 1931-1932. Przekłady Trenów Jeremiasza w narzeczu trocko-karaimskiem. - Rocznik Orjentalistyczny 8: 181-192.

Zajączkowski A. 1932. Sufiksy imienne i czasownikowe w języku zachodniokaraimskim (przyczynek do morfologji języków tureckich). Les suffixes nominaux et verbaux dans la langue des Karä̈ms occidentaux (contribution à la morphologie des langues turques). [Prace Komisji Orjentalistycznej Polskiej Akademji Umiejętności 15]. Kraków. 